perception; absence does not appear. Sextus, in Against the Logicians, speaks about naturally non-evident things, including the soul, which are "everlastingly hidden away." We may not perceive absence, but that does not preclude a non-perceptual awareness of it, whatever that might be.

\title{
Early Buddhism and Incommensurability
}

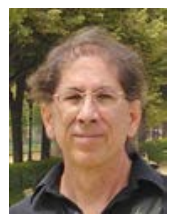

\section{Christopher I. Beckwith}

Department of Central Eurasian Studies,

School of Global and International Studies, Indiana University

beckwith@indiana.edu

Charles Goodman (henceforth G)'s Response to the thoughtful paper by Adrian Kuzminski ("Early Buddhism Reconsidered") in this volume is actually devoted mainly to my book Greek Buddha (2015). Half a century ago, Thomas Kuhn famously coined the term incommensurability to refer to the inability or unwillingness of many scholars in a given field to understand substantially new ("revolutionary") work. He describes their reactions against it and their attempts to suppress or discredit it. The reason for their response is that new discoveries advance science by challenging and displacing old beliefs and practices. Kuhn accurately describes G's Response.

When I wrote Greek Buddha, I assumed that the potential readership would be people interested in a major topic of intellectual history that has been neglected for a long time, people who are able and willing to think about an alternative to the problematic received views. In general, that has proved to be the case. Kuzminski, the author of an excellent book on later Pyrrhonism (especially Sextus Empiricus) and later Buddhism (especially Nāgārjuna), states in his paper that my book makes a significant contribution toward solving the problems it addresses. Unfortunately, by contrast, G takes selected bits out of their contexts in my book, puts them into new contexts of his own making, and then deconstructs his own creations.

Thus at the very beginning of his Response, G gives a story that he has written himself, but attributes it to me, saying: "The second, more elaborate narrative summarizes the views stated or clearly implied by Christopher Beckwith in his book Greek Buddha." However, I do not say or imply anything like it, as may be revealed by even a cursory reading of the relevant sections of the book, including my explicit conclusion on that particular topic on page 121 .

$\mathrm{G}^{\prime}$ s basic argument throughout is that the truth about ancient Buddhism (i.e., actual "Early Buddhism") is already known from the portrayal of antiquity in texts of late Normative Buddhism, which are centuries younger 
than the dated sources for Early Buddhism and represent a radically different system. But unless Normative Buddhism, including its modern form, preserves the exact words of the Buddha, it has changed, like all religions. Normative Buddhism is first attested in around the first century C.E., half a millennium after the Buddha. Normative Buddhist texts portray something drastically different from the dated, contemporaneous Early Buddhist testimonies - the hard data on that form of Buddhism. Several long sections of Greek Buddha analyze, in great detail, the account of Early Buddhist sects in Megasthenes (fl. 305-304 в.C.E.) and the religious content of the early third century B.C.E. Major Inscriptions of Devānāmpriya Priyadarśi. (In my book, I establish which inscriptions were not inscribed by the Mauryas but by a much later ruler of the Normative Buddhist period named Aśoka.) These sources show that Normative Buddhism - a radically changed belief system compared to attested Early Buddhism-developed under the Sakas and Kushans. G says not a word about my book's in-depth coverage of this.

As far as I know, Greek Buddha is the first monograph devoted to carefully examining, studying, and thinking about the dated Early Buddhist inscriptions and manuscript data with the goal of discovering what Early Buddhism was really like. Throughout his Response, G's authorities are undated late Normative Buddhist texts. These texts are filled with marvels recounted in the traditional-modern Buddhist "frame tale" based on the late canonical literature of early Normative Buddhism (which is unattested until some 500 years after the Buddha), the magical fantasies that fill the hagiographical literature of medieval Buddhism (mostly a millennium or more later than the Buddha), and the modern "popular" misinterpretation of Buddhism that non-devotional Buddhologists have been fighting against for at least a century. Normative Buddhism certainly deserves study for its own sake. However, my book has nothing to do with the late Normative Buddhist stories about Early Buddhism except to note that it is not based on them and does not discuss them.

The limited time and space available to me for this reply allow me to discuss only a few examples of the inaccuracies in G's long Response.

G criticizes my interpretation of the Buddha's epithet Sakamuni Sakyamuni (attested rather late, in very many spellings). Although I do think the Buddha seems to have been a Scythian, it is actually not terribly important either way, as noted in my book. However, the epithet's form is relevant. The significance of Bareau's (1987) paper on Lumbini is its definitive demonstration that the story of the Buddha's birth there is a later fabrication-and that is the reason I cite it. G's comments about it are irrelevant. They show he has missed not only my point but also the main thrust of Bareau's paper, in which the only real error is Bareau's acceptance of the traditional claim that the putative "Aśokan" inscription there is a genuine "Mauryan" period text. Bareau remarks that the inscription is the only reason for thinking the Lumbini site is "old." Here is where the spelling 
Sakyamuni on the inscription becomes important. Though G concedes that the epithet could mean "the Scythian sage," as I argue, he says "of course, the substitutions of $S$ for $\hat{S}$ and a for $\bar{a}$ are enough to mark Sakyamuni as Middle Indic."

That is not quite correct, but also not the point. The point is that the form on the inscription has the telltale, uniquely Sanskrit $-y(a)-$, showing that it is a relational adjective. ${ }^{1}$ But with the extension -ya, it is a specifically Sanskritic formation that should not occur in Prakrit. The text is otherwise in Prakrit, as are all the other "Aśokan" inscriptions, including the Major Inscriptions of Devānāṃpriya Priyadarśi, which are explicitly dated to the early-mid third century B.C.E. By contrast, the earliest possible date for the earliest attested text in Sanskrit is the first century B.C.E. The contents of the unusually short Lumbini Inscription are solidly Normative Buddhist as well, meaning it is late. These bits of data indicate that the inscription was added to the pillar no earlier than the first century B.C.E., and probably much later. (Contra G, it is known that there were once many blank "Mauryan" pillars, as I discuss, with source citations, in my book.) In short, the Lumbini Inscription must be a forgery. It probably dates to the late Saka-Kushan period, around the second to third century C.E., half a millennium after the Major Inscriptions, when Sanskrit was spreading and displacing Prakrit and when the Lumbini site was being developed as a pilgrimage destination.

In Greek Buddha, I discuss the Achaemenid Persian conquest of Gandhāra and Sindh, the introduction of Early Zoroastrianism around the empire (not Late Zoroastrianism, as I explain very carefully), and the relationship of that faith's tenets to the Buddha's enlightenment, and thus to Pyrrho's. G says, "But what evidence is there that the version they were opposing was a Zoroastrian form of eternalism? So far as I am aware, there is none; certainly Beckwith provides none." No, I do provide evidence about the Early Zoroastrianism the Buddha reacted to by negating its key features, G just neglects to mention it. I say nothing at all about "eternalism." The connection is clear from the beginning of the Aristocles Passage alone-though it is necessary to read, pay close attention, and think about that passage (all of it) and its explication, including its full contexts, in order to understand it. In it Pyrrho even uses the classic antilogy of TRUTH versus the LIE, which permeates Early Zoroastrianism. These two terms are also examples of pragmata, the topic of the Aristocles Passage and a term I discuss at length and in detail, with many examples and discussion of the literature, in several places in my book. Yet $\mathrm{G}$ goes on about pragmata as if my book had not been written, also ignoring the extensive literature. He even argues that pragmata were not ethical for Pyrrho, and worse, contends that considering them to be ethical is a modern idea. That is exactly the opposite of what the sources actually say. (G seems to have overlooked most of my discussion of pragmata, and also the extensive scholarly literature on Early Pyrrhonism, though all scholars who have worked on 
Early Pyrrhonism recognize the importance of the Aristocles Passage and typically discuss it at length.) As I show in Greek Buddha, although nonethical usages of the term pragmata are certainly possible, there are no examples in the sources on Pyrrho, which also explicitly note that he taught ethics. The same is true of the use of dharmas in the late Normative Buddhist texts' much altered representations of Early Buddhist thought and practices. So the question is: What is the Buddha negating in the Trilakșana, and Pyrrho in his version of it? The perfectionist system of Early Zoroastrianism is historically known to have been introduced into Gandhāra by the Achaemenid Persians. Without it, we would have to invent an identical system to explain what the Buddha rejects in the Trilakșana.

$\mathrm{G}$ insists on the popular modern mistranslation of the Trilakșana's first characteristic (in Pyrrho's order), anātman (Pali anattā), as "no soul," flying in the face of even traditional interpretations, which give the meaning "no essence" (etc.) alongside "no soul." In serious (non-"popular") Buddhological scholarship, it is now generally accepted that it did not mean "no soul," as I note, with citations, in my book, though negation via anātman can include the idea of the (human) soul as well as other non-ethical categories, such as BUNNy. G says, "The word ātman means 'self' and 'soul' in the Atharva Veda, a text that is far older than Buddhism. Ätman means 'self' and 'soul' in the $S B \mathrm{Br}$ and the Upanișads. Átman means 'soul' in texts that are old, but younger than Buddhism, such as the Gìtā. In the latter half of the first millennium CE, ātman is attested as meaning 'logical differentia'." G lists works that are actually not attested until well into the Middle Ages, if not later, so that they are all actually "younger than Buddhism," including the Atharva Veda, which according to Buddhists is not even a Veda at all and in any case certainly should not be lumped together with the "other" three Vedas, and of course including the Brāhmanas and the Upanișads. As noted in my book, there is little or no hard evidence that these works even existed as texts until the second millennium C.E. Where are the ancient manuscripts? Where are the early medieval ones? There are none, and few or no references to such works in genuinely early texts, yet G's discussion is full of the unquestioned traditional belief that they all existed in ancient, even primordial times. At the end of his list G mentions that ătman is attested in the Early Middle Ages in the meaning "logical differentia." That is the precise technical sense of Greek diaphora, the characteristic that Pyrrho negates as adiaphora in his version of the Trilakșana, as discussed below. Though early medieval, it is actually early for Normative Buddhism, and suggests the continuation of an ancient tradition. Thus, although $G$ seems to misunderstand Greek adiaphora "undifferentiated, without a logical differentia," it does correspond very well to anātman in Early Buddhism.

With regard to the middle term, G actually agrees with the alternate traditional Indological etymology of duhkha (dukkha) that I cite, as originally meaning something like "unbalanced, unstable," which is also the literal meaning 
of its Greek equivalent astathmeta in Pyrrho's version of the Trilakșana. It is manifestly clear that these two terms, as terms, correspond very well to each other. Yet after agreeing with my analysis, G says, "this kind of etymological analysis can tell us only that the word duhkha might have meant 'unstable,' ... [but in] the texts of what Beckwith calls 'Normative Buddhism,' the extremely common word duhkha/dukkha has two closely related primary meanings: 'suffering' and 'pain'." G thus insists nevertheless that the views of Normative Buddhism, particularly its modern "popular" form, tell us what historical Early Buddhism was like, despite a gap of over half a millennium. Yet practically every serious modern work on Buddhism rejects the validity of translations like "suffering" (q.v. below), which also make no sense in the Early Buddhist context.

Pyrrho's third term, anepikrita "undetermined, unjudged, unfixed," is a rare word in Greek, but a parallel text that quotes Timon on Pyrrho indicates the original term in his text must have been a related form (built on the same root) that in the positive means "determined, judged, fixed" or the like, supporting the attested form and its correspondence to anitya (anicca), which is explained even in traditional Indological works cited by G as "impermanence (continuous change of condition)" (Rhys Davids \& Stede 1921: 355), from a- "not" plus nitya "continual, invariable, fixed" (Monier-Williams s.v. nitya), therefore anitya "impermanent, variable, unfixed." G does not discuss any of this. Instead he declares, "nothing about the Greek word or the context of the passage provides the slightest justification" for my interpretation that links them. But he then contradicts himself, declaring, "As it happens, powerful arguments can be made that there are philosophical links between the concepts of impermanence and of (ultimate) unjudgeability."

As noted above, the original literal meaning of duhkha (dukkha) remains controversial, but $G$ actually agrees that my proposal on it (i.e., on its meaning in attested Early Buddhism) is a likely solution. He concludes, nevertheless, "the meaning of duhkha that Beckwith assumes for his argument is not, so far as I know, attested in any text, in any period of Indian literature." But that is the equivalent of saying we should expect a superstar to be "a celestial phenomenon," like a supernova. Is superstar used in any text of American English literature in its apparent literal meaning? Words are metaphoric, allusive, and impermanent-they are unfixed, and change constantly in form, semantics, and function. They are also frequently loanwords. Certainly it is difficult to determine what duhkha really meant to the Buddha and to the Early Buddhists, but that is partly because previously no one seems to have studied the hard data sources on Early Buddhism, or even realized that there were any. Why not? No doubt they believe they already have what they need: the texts of late Normative Buddhism, which tell us the Truth about what the Buddha taught.

The Trilakșana (in the Normative Buddhist order) says that all dharmas ("constituents" of anything) are anitya "impermanent (or unfixed)," and 
duḥkha, and anātman "without an inherent essence, nature, character," i.e., "without an inherent self-identity (including the idea of a 'soul')." Now, the Trilaksana is not some obscure passage found only in one text, it is perhaps the central teaching of Buddhism as a whole from the earliest times through the early Normative Buddhist period to the present, and is still taught as such even in general introductions to Buddhism for nonBuddhists. It is thus not surprising that it is also the core teaching of Pyrrho. Yet G says in the conclusion to his response, "If, though, unconditional acceptance and suspension of judgment is a path to peace, that sounds like a basic feature of the human condition, one that should be accessible to people everywhere. What would stop South Asians, Chinese, and Greeks from discovering this truth independently?" According to him, then, this reductionist "truth" — which omits not only Pyrrho's "three characteristics," but also the Buddha's Trilakșana, the foundations of the entire system of Early Buddhism-all is actually unimportant and undistinctive. As a result, everyone in the world is actually a Buddhist. Yet a central goal of Buddhist meditation is to understand the Trilakșana. Why? Because it is difficult to truly understand, as attested by the generations of scholars who have tried unsuccessfully to understand the Aristocles Passage. How has $\mathrm{G}$ concluded it is all a trivial universal belief?

$\mathrm{G}$ repeats the tradition that contends the term śramana (samana) applied also to Jains and others at the time of the Buddha. Yet there is absolutely no textual, archaeological, or any other evidence for the existence of Jainism before the Common Era. Moreover, as late as the early centuries C.E., all known hard-data attestations of the word śramana, in the many languages in which the word occurs, are still exclusively to Buddhist practitioners. Either $\mathrm{G}$ did not actually read the relevant sections of my book where this topic is discussed at length and in great detail, or his evident belief in the medieval Normative Buddhist fantasy about Indian antiquity kept him from understanding them. Attested Early Buddhism is based on contemporaneous accounts or references preserved in dated texts and inscriptions and archaeological finds. That excludes the medieval fairy tale about ancient India, as well as the frame tale of most-perhaps all-canonical texts as we have them (as Schopen and others have demonstrated), including references to the Jains, whose teachings the Normative Buddhists wanted to invalidate or refute, so they made the Buddha do it himself, in Normative Buddhist texts.

$\mathrm{G}^{\prime} \mathrm{s}$ response to another new proposal is, "So far as I am aware, scholars who have studied this topic think these concepts were developed in India, probably just before or during the time of the Buddha. Indeed, we have excellent evidence for this claim. The Upanișads ..." He thus ignores the demonstration by other scholars that virtually all putatively "early" Indian texts (with the exception of the "old" parts of the Rig Veda) ${ }^{2}$ reflect Buddhist thought, and he also ignores the unavoidably hard fact that 
those putatively "early" non-Buddhist Indian texts are not actually attested or verifiable in any form until well into the Common Era. Such texts do not attest anything ancient, and historiographically they by no means outrank the genuine ancient evidence studied in Greek Buddha, including discussion of the important, still neglected sources on Early Brahmanism (which is not the same as later Brahmanism, not to speak of Hinduism). G does not mention this or apparently anything else in that section. Instead, he attempts to use material I cite against me, implying that I am unaware of the fact that, as he says, "the Pāli Canon, ... the Mauryan pillar inscriptions, [and] the testimony of the Greek traveler Megasthenes ... support the conclusion that at least some early Buddhists believed it was possible ... to go to a heavenly realm after death." He then accuses me of "simple ignorance." In fact, I discuss this topic at length in my book, and it is clear from his text that he actually learned about the topic from reading it there.

As one last example, G asserts, "Sometimes Beckwith treats secondary sources with as little care as primary ones. For example, he cites a fine article by André Bareau as showing that the story of the Buddha's birth at Lumbini is 'fictitious,' using this to bolster his claim that the Lumbini inscription is spurious." G's discussion, which is as full of unpleasantness as much of the rest of his Response, actually rejects Bareau's demonstration that the story is a fake. He thus misses Bareau's key point, namely, as G himself says, "that Gotama was not born at Lumbinī." G quotes a sentence of Bareau's paper in French, apparently thinking that it provides the coup de grâce, but Bareau says straight out in it that the Buddha " $n$ 'est pas né à Lumbini"-i.e., he "was not born in Lumbini." Whatever else Bareau says or does not say in his article is irrelevant for the point in question, which is to show that the story of the Buddha's birth at Lumbini is fictitious.

Returning again to G's conclusion, he says, "What would stop South Asians, Chinese, and Greeks from discovering this truth [q.v. supra] independently? We need not pull and wrench at our evidence to force every teacher of equanimity in Eurasian history into a single historical tradition." Leaving aside the oddly belligerent attitude of this statement, the idea is clearly the reduction of Early Buddhism to an imagined simplistic universal, "equanimity," combined with magical thinking.

But $G^{\prime}$ 's statement has more implications than it might seem. His idea that everything is possible and can be explained as coincidence is an attack on science and on rationality itself, including the very idea of enlightenment. In our terribly troubled world, we already have too many attacks on what is left of civilization. We need the ideal of the Buddha, the genuinely heroic thinker. Pyrrho, following in his footsteps, teaches that thinking is salutary, and not having passionate beliefs and hatreds leads to passionlessness and peace. So recommended. 


\section{Notes}

1 - Whitney (pp. 457-461) classifies such forms as derivatives in ya with initial vrddhi-strengthening, giving as an example lāukyá "of the world" from loká.

2 - G says, "Beckwith does indicate in passing ... that he is prepared to accept the four Vedic Saṃhitās as both South Asian and old," citing "Beckwith p. 176." However, my book does not even mention the "four Vedic Saṃhitās," on page 176 or anywhere else. 